\title{
Salers Protected Designation of Origin cheese, France. The diversity and paradox of local knowledge in geographical indications
}

\author{
Laurence Bérard ${ }^{1}$, François Casabianca ${ }^{2}$, Marie-Christine Montel $^{3}$, Claire Agabriel $^{4}$, Rémi Bouche ${ }^{5 \dagger}$ \\ ${ }^{1}$ CNRS Ressources des terroirs, F-01000, Bourg en Bresse, France \\ e-mail: laurence.berard@ethno-terroirs.cnrs.fr (corresponding author) \\ ${ }^{2}$ INRA-SAD, Laboratoire de recherches sur le développement de l'élevage, F-20250, Corte, France \\ e-mail: casabianca@corte.inra.fr \\ ${ }^{3}$ INRA, Unité de recherches fromagères, F-15000, Aurillac, France \\ e-mail: cmontel@clermont.inra.fr \\ ${ }^{4}$ VETAGRO-SUP Campus de Clermont-Ferrand, 63370 Lempdes, France \\ e-mail: c.agabriel@vetagro-sup.fr \\ ${ }^{5}$ INRA-SAD, Laboratoire de recherches sur le développement de l'élevage, F-20250, Corte, France
}

Submitted: 18 July 2015. Accepted: 17 November 2015

\begin{abstract}
Our case study of Salers cheese production in south-central France highlights how place-specific knowledge grounds the various networks shaping the rise of geographical indications (GI) in food production. In 1961, Salers cheese producers created a "Protected Designation of Origin" (PDO). To preserve the distinctive character of their product, they opted to require use of the gerle, a traditional wooden vat, and an on-farm cheese making process. The gerle came recently under scrutiny from French governmental hygiene regulation enforcement, and the subsequent public controversy jeopardized the entire supply chain and destabilized Salers cheese-making methods. Prevailing in their efforts to protect Salers, producers established the gerle as mandatory and have since set up a governance board to ensure PDO brand integrity. Our analysis suggests that the diversity of technical choices and associated set of knowledge in Salers cheese production has paradoxically been both its strength and weakness. Local agricultural know-how forges links among participants in Salers networks, connecting cheese producers and consumers, to cattle, microbes, landscapes, wooden tools, and cheeses. Yet, diversity of local expertise creates a tension among producers who must collaborate to achieve unified standards within a PDO while resisting homogeneity. Such results contribute to discussing on PDO governance: an arena to share, compare, and unite local knowledge is critical for GI and thus for sustainable agricultural systems.
\end{abstract}

KEYWORDS: Salers; geographical indication; local knowledge; dairy farming systems; cow cheese; supply chain.

Citation / Cómo citar este artículo: Bérard, Laurence; Montel, Marie-Christine; Agabriel, Claire and Bouche, Rémi (2016) "Salers Protected Designation of Origin cheese (France). The diversity and paradox of local knowledge in geographical indications". Culture \& History Digital Journal, 5 (1): e006. doi: http://dx.doi.org/10.3989/chdj.2016.006.

RESUMEN: El queso con Denominación de Origen Protegida Salers (Francia). La diversidad y las paradojas de los saberes locales en indicaciones geográficas protegidas.- Nuestro caso de estudio sobre producción de queso de Salers, en el centro-sur de Francia, ilustra cómo los saberes específicos locales explican el origen de la formación de una indicación geográfica (IG). En 1961, los productores del queso de Salers crearon una denominación de origen protegida (DOP). Para preservar el carácter distintivo de sus productos, optaron por requerir como condiciones necesarias tanto el uso de la «gerle», una cuba de madera tradicional, como el hecho de que la producción del queso se haga en la propia finca por el ganadero y con la leche de sus propios animales. El uso de la «gerle» fue objeto de examen por parte de las autoridades regionales francesas desde el punto de vista de la aplicación del Reglamento de higiene en la producción de quesos. La subsecuente controversia pública sobre la idoneidad higiénica de las cubas 
puso en peligro toda la cadena de producción y desestabilizó los métodos de fabricación de queso de Salers. En sus esfuerzos para proteger el queso, los productores establecieron la obligatoriedad de utilizar la «gerle» y se creó un Consejo Regulador para garantizar la calidad específica de la marca colectiva de la DOP. El artículo sugiere que la diversidad de opciones técnicas y el conjunto de saberes asociados a la producción local de queso de Salers han constituido, paradójicamente, tanto su fuerza como su debilidad. El saber agrícola local forja vínculos entre los participantes en las redes del queso de Salers, conectando a los productores con los consumidores, el ganado, los microbios, los paisajes, las herramientas de madera y los quesos. Sin embargo, la diversidad de saberes expertos locales constituye un elemento de tensión entre los productores que les obliga a colaborar entre sí para alcanzar estándares unificados dentro de la DOP. Los resultados del trabajo contribuyen al debate sobre la gobernanza de una DOP: un espacio para compartir, comparar y unificar el saber local es un factor clave para el buen desarrollo de una IG y, por tanto, para construir sistemas agrícolas sostenibles.

PALABRAS CLAVE: Salers; indicación geográfica; saber local; sistemas de producción lechera; queso de vaca; cadena de suministro.

Copyright: (C) 2016 CSIC. This is an open-access article distributed under the terms of the Creative Commons Attribution License (CC BY) Spain 3.0.

\section{INTRODUCTION}

The concept of Geographical Indication (GI) is designed to protect a product's name based on particular qualities derived from its geographical origin. The two main pillars of this initiative are the identification of the geographical area that is entitled to use a particular name, and the specification of production methods. Particular knowledge and skills are essential factors in establishing the link with origin (Bérard and Marchenay, 2004). The establishment of the rules of production raises multiple questions which this research aims to address. Yet, the choice of techniques covered by specifications, and the way those specifications are applied and used by the different players in question, are all expressions of local balances of power. Subsequent misunderstandings and misappropriations may be seen as defects by the authors of those specifications. However, such divergent opinions and techniques may also express the dynamism, vitality, and even resistance of a local community facing homogenizing forces from the highly concentrated agribusiness industry. Decisions made for the GI may therefore be seen as a powerful marker of the pressures, issues, and paradoxes present in all local production sectors, because here, more than anywhere else, the skills associated with the recognition of a GI belong within a community that has its own codes.

Historically, countries in Europe utilized their own geographic origin labels: AOC (appellation d'origine contrôlée) and the Italian and Spanish DO (denominazione di origine in Italy; denominación de origen in Spain). In 1992, the EU created a continental PDO label. To qualify for PDO status, farmers must prove definitively that the properties and characteristics of their product are particular to its place of origin. Accordingly, it must be produced, processed, and prepared entirely and exclusively within that region to merit the proposed PDO name. The certification process begins locally, with producers applying to their national government for an official designation, and if approved, the respec- tive government applies to the EU, which ultimately grants (or not) the PDO. In this manner, the building of a PDO brand thus implies a pooling of skills and collective action in defense of a shared asset. Yet, situations vary considerably from one PDO to another. As this paper aims to demonstrate, it leaves considerable room for local discretion.

\section{SALERS PDO CHEESE}

Salers cheese is a prime example of the difficulties faced by producers in asserting a unified code of production. As one of the five "flagship" cheeses of the Auvergne region in south-central France, Salers epitomizes the artisanal quality that GIs attempt to support. The Auvergne region boasts fertile soil atop volcanic mountain hillsides covered in native wildflowers and wild grasses. Farmers and herders of the area have kept alive ancient dairy farming techniques, specific to this landscape. Cheese exemplifies this agrarian artisanal heritage.

Formerly part of the Cantal Protected Designation of Origin (PDO), in 1961 Salers became a PDO in its own right in a bid to protect and preserve a system of freerange production relying on traditional skills. These are upheld as such in the process of differentiating from a GI that is seen as overly generic. One of the cheese's most original features is that the raw milk must be curdled in a wooden tub, known as a "gerle", which plays a key role in the local cheese culture (Didienne et al., 2012) and is part of the specifications. Recently, it was at the centre of serious debate launched by producers taking advantage of sanitary rules to point out the potential dangers of wooden containers. Food safety regulation rejects this traditional form of production, with hygienists who prefer to sanitize and do not consider spontaneous microbes positively, as Latour (1988) describes in "Pasteurisation of France". Hygienists follow and perpetuate a particular discourse of sanitation, and work to inscribe it as scientifically incontestable — "to speak of hygiene was already to take up a position" (Latour, 1988). Here microbial pol- 
itics echoes long-standing explorations of the politics of scientific authority (Foucault, 1980; Dove, 1996; KnorrCetina, 1999; Fischer, 2000). The historical phenomenon of pasteurization, as chronicled and analyzed by Latour, parallels the current fixation on sanitation in cheese production:

Wherever the microbe may find itself, an authorized agent must be there to chase it away. If militant hygiene achieved this aim, it had created a new source of power, a power unthinkable a few decades earlier and one that was rapidly becoming irreversible (Latour, 1988).

Thus, traditional material such as wood is forbidden, and even though dispensations exist for hygiene, it is very difficult to obtain them (Bérard and Marchenay, 2008). The application of European food safety regulations depends on the economic and cultural background of each country. It leads to economic restructuring (Dunn, 2003). In France, the great diversity of traditional products is threatened by it and the farmers' scale suffers from it. Today, the divisions within the Salers sector between those for and against the gerle have left the entire sector seriously weakened at a time when it must unite to confront and resolve its internal contradictions within a production context where investment in time and labour reinforces individualism

\section{ACTOR NETWORK THEORY AS RELEVANT FRAMEWORK}

The concept of actor-networks could help scholars and farmers to re-conceptualize the role of traditional agricultural knowledge in GI food production. According to actor-network theory (ANT) "entities take their form and acquire their attributes as a result of their relations with other entities" (Law, 1999), such that social, economic, political, and technical factors do not provide the background for activity and interactions between actors - they are themselves built into the networks. "Network" here refers to the active process of forming and being formed by other actants, "a series of transformations - translations, transductions - which could not be captured by any of the traditional terms of social theory" (Latour, 1999). ANT deliberately includes non-human entities as actants ${ }^{1}$.

An innovation is but a syntagmatic line (i.e., a line connecting programs to further programs) containing human and non-human actants that were recruited to counter the anti-programs (Czarniawski and Hernes, 2005).

Our orientation is that local knowledge and knowhow form the core that binds all elements in a socio-technical network - humans, objects, and discourses - as per the actor network theory (Callon, 2004). In line with Akrich (1992), we agree that "technical objects participate in building heterogeneous networks that bring together actants of all types and sizes, whether human or non-human". From this perspective, the code of practice for Salers PDO cheese could be seen as a technical object that also entails social dimensions. Sharing competencies among all actants in the network becomes a main support for the future of the PDO and the continuing existence of this cheese. The emergence of a learning process may be based on two-way exchange (Callon, 1998) and built on this common knowledge. This will give more strength to collective democracy and to individual producers as well.

In line with such ANT analysis, we assume that the gerle is core in the Salers Actor Network's constitution and evolution. But we must consider also two other components of the local situation to be articulated with the approach of the Salers Actor Network. First is the coordination capacity of the local actors and we discuss the consequences of the Salers stakeholders' diversity as we could observe, according to the framework proposed by Ostrom (1990) on the common-pool resource management. We focus on the content of the specification rules and on the great absence of some key-elements such as rules concerning the breeds. Second is the nature of producers' technical practices and choices together with the stakeholders' strategies, using the approach of collective action provided by Olson (1987). So, we try to face the complexity of the Salers situation thanks to a crisis period that revealed how these elements are interacting and gave us the possibility to an in-depth study of the concrete conditions for collective action.

At the center of our analysis of the Salers Actor Network, we find a fundamental point of tension between the importance of diversity within agricultural systems, and the need for collective unity among those producers who must defend the system, particularly when, as in our case, it has been codified in the form of a PDO. Thus, our hypothesis is to assume that the diversity of local agricultural knowledge among the Salers farmers is paradoxically providing both strength and weakness to the whole sector.

\section{DIVERSITY WITHIN THE LOCAL AGRO-FOOD SYSTEM}

Reinforced by economic history and the weight of sanitary requirements, an important diversity characterizes this supply chain based only upon on-farm processing. It is appropriate to approach this concept of "diversity" with attention, to explore it. Is any diversity favorable? Within a collective feature, do some kinds of diversity potentially weaken the position of the organization? To what extent do we identify deconstructing heterogeneity as presenting paradoxes?

As a public process, the founding and development of a GI is fully controlled by the local producers' organization known as an "Organisme de défense et de gestion" (Protection and management body). Under the French system, this organization is responsible for the first draft of the code of practice (gathering together the product requirements and production rules) submitted to the INAO. ${ }^{2}$ 
As a consequence of new European and French regulation relating to the local organization and within the timescale of our research work, a Salers section has been created within the regional CIF (Regional board for local cheese industry, a common body shared with the Cantal PDO). This is now the real authority for any decisions relating to the cheese and its producers' problems and for relationships with other authorities. At the conclusion of our fieldwork, we regard this new section as our primary interlocutor.

The finality of our work explores the link between GIs and sustainable development. It provides a framework for a multidisciplinary approach combining researchers in anthropology, cognitive ergonomy, microbiology, and livestock science. Coordinated by INRA (the French National Institute for Agricultural Research), ENITAC (the Clermont School of Agricultural Engineering - this school joined recently the Vetagro-Sup that has been created meanwhile) and the CNRS (the French National Centre for Scientific Research), the research methods included ethnological and film research, strategic analysis, a study of livestock practices, and microbiological evaluation.

Researchers pooled their methods throughout the 2006 and 2007 seasons in a bid to analyze the Salers supply chain and understand its main trends. As part of this process, interviews were conducted with 17 producers, four cheese ripeners, two technicians, one gerle maker, and officials from the CIF and the regional INAO centre. Our approach was to gather information by focusing on local skills in terms of their status (individual or collective), their development, and their transmission. We also made video recordings of cheese production, and used these tapes to collect the views expressed by producers, technicians, and trainers.

Finally, we reported our main findings on 2008 to the Salers section, together with representatives from the CIF and the regional INAO centre. The objective was to help decision making at the local level, with regard to the major issues surrounding the development of the code of practice, and also to explore opportunities for strengthening authentic production. After this period of field study ended by the report to the Salers section, we stop our work as the ANR project (dedicated to the link between GI and sustainable development) where our work was included was ended, and we had no more means to do such work. So, we ignore the further evolution of the local situation.

The first part of this article discusses the paradoxical trajectory of this free-range production that exists alongside its industrial neighbour but is the victim of its economic success as well as a strong sanitation controversy. It continues by analyzing the effects of producers' technical, economic, and cultural choices on the perpetuation and/or evolution of knowledge, within a sector that allows the coexistence of a wide range of factors. From there, it discusses the results and goes on to explore the collective difficulties faced by producers in forming a separate official entity.

\section{THE SALERS PDO: A PARADOXICAL TRAJECTORY}

\section{A Local Industry out of step with productivity}

The local production of Salers cheese stands in contrast to the powerful industrial sector that grew up around traditional Cantal-type cheese production in the late 1960s. Intensified production was based on the direct implementation of technologies first introduced to improve output in the milk-producing area of the Massif Central. The result was a selection process that ruled out many local cheese-making traditions, alienating a number of producers who set up the independent Salers PDO.

Without revisiting those negotiations in detail, it is worth noting a few major issues that remain relevant today (Delfosse, 1992). The established Cantal PDO could have advanced free-range production instead of creating a new PDO. It was not the choice of the Salers producers. Seasonal free-range production is a key feature of the Salers specifications. Salers cheese is based on the raw milk of a single dairy herd, processed twice a day following each milking, in a wooden container called a gerle. The cattle are essentially pasture-fed; each herder is required by law to declare his or her period of turn out to pasture. The regulations state that cheese made exclusively from the milk of the Salers cattle breed could be labelled "Tradition Salers".

The Salers production sector covers some hundred producers and a wide range of farming practices. This must be seen in relation to the region's economic history, which is closely linked to that of the Cantal PDO. The late 1960s brought a decline in demand for free-range cheese that gradually led producers to concentrate on milk production. The same period saw the development of cooperatives and industrial cheese plants. Some herders remained faithful to the Salers breed but most turned to more productive, less demanding breeds such as Holstein and Montbéliarde cattle (Ricard, 1994; Delfosse, 1992).

Two decades later, "cheese making" was back in fashion and Salers cheese became a profitable business once again, helped by milk quota restrictions, falling milk prices, and growing consumer interest. Many young cow herders started making cheese, supported by bank loans from the Credit Agricole that were sometimes conditional on abandoning the Salers breed.

Production is a complex process (Photos). Renneted milk is left to curdle in the gerle at a temperature of 30$34^{\circ} \mathrm{C}$. The curds are then sliced, reformed, and sliced again, before pressing several times in a special cheese press. This is left to acidify and mature for 8-12 hours before grinding, salting, and stirring by hand. After a second, shorter ripening stage, the ground and salted "tomme" is hand-fed into cylindrical moulds where it is pressed for 48 hours and turned several times. This twicea-day production is substantial work.

Ripening continues for at least three months starting from the day of moulding, with the cheese turned and 




Рното 1. Open-air milking a herd of cows belonging to the Salers breed, with the presence of the calves.



Рното 2. The « gerle » in action, with the beginning of decurding.

wiped at regular intervals. Ripening is almost always carried out by third-party ripeners who, like the producers themselves, are diverse. An increasing number are integrated within the supply chain. The most powerful also produce Cantal cheese and does have some influence on Salers cheese making.

Throughout its 40-year existence, the Salers sector has thus maintained traditions that its powerful neighbour has discarded. The two sides went their separate ways, Cantal production evolving while Salers produc-

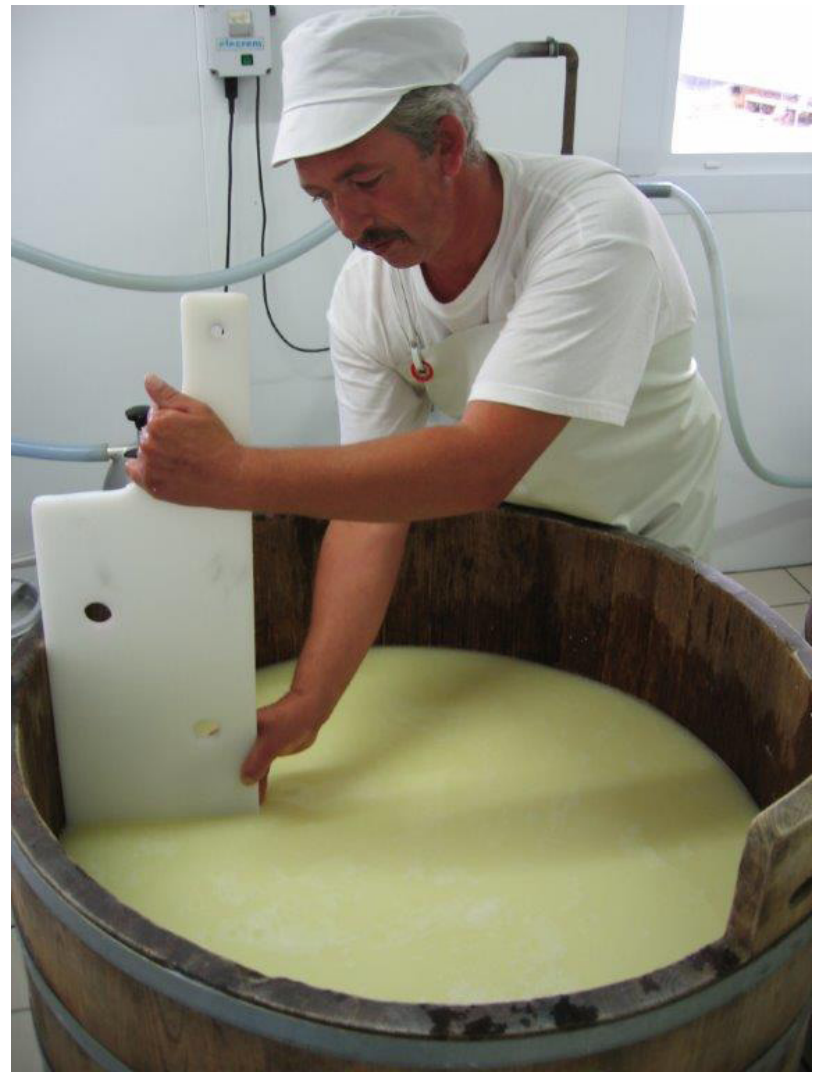

Рното 3. The curd is gathered in the gerle (Gaec des Coches). 




Рното 4. Cutting the « tomme » before grinding, salting and stirring.

tion remained more or less unchanged. There are striking contrasts between the two: Cantal pursues productivity-based, large-volume output and low milk pricing; Salers is devoted to low-volume, small-scale production, linked to an image of authenticity and specific character. Salers cheese, until the late 1990s, served to demonstrate how far Cantal production departed from local traditions. But the situation is not as clear as it seems. In the same period, the Cantal sector underwent significant development with careful consideration being given to its quality objectives. The Cantal PDO had serious problems with very low mass-market cheese prices, which in turn depressed the price of local milk to below the national average. The Cantal PDO board therefore tried to modify the rules, looking to raise the perceived status of its cheese by raising the quality.

The progress made by Cantal did help to re-energize the entire sector. It was then that the gerle controversy escalated, focusing attention on the sanitary status of the livestock required for Salers production. Despite a favourable outcome for the gerle, now confirmed as compulsory, the INAO still expects producers to do more work in the area of milk quality and the hygiene of tools and premises. In a move to support Salers producers, the INAO also recommends tightening the specifications of the gerle in terms of capacity, shape, type of wood, etc.

Reinforcing quality initiatives within the context of an industrialized sector created a new and dynamic image for the Cantal cheese industry. Meanwhile, the Salers supply chain seemed backward due to the suspicion surrounding its traditional, free-range practices, based on raw milk and wooden tools. Interestingly, however, research increasingly indicates the benefits of wood (Devoyod et al., 1987; Mariani et al., 2007) and raw milk (Michel et al., 2008). This comparison was made all the more striking by the absence of a structure specific to each PDO. In 2007, 1574 t of Salers cheeses were produced by 86 producers. By contrast,

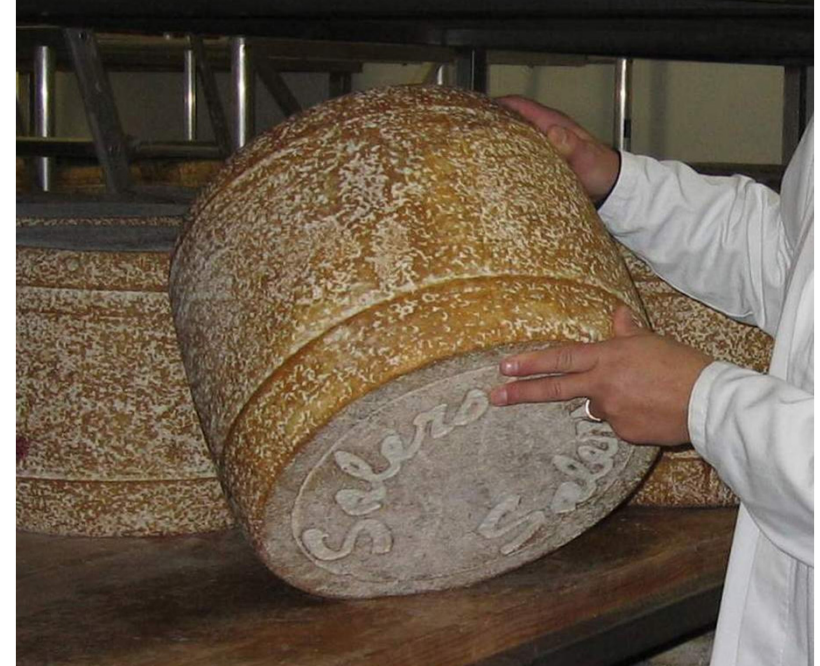

Рното 5. Salers cheese ready to be sold, after some months of ripening.

production of Cantal cheeses was 17900 t. of which $98 \%$ was produced by 14 dairy plants representing more than 2000 producers (data from Agreste, the office for agricultural statistics and studies, and DRAAF Auvergne, the French regional authority for foods, agriculture, and forestry in Auvergne). The map (see Figure 1) shows the production areas for Salers and Cantal cheeses. However, thanks to the strong Cantal organization and the CIF resources, the Salers sector found enough funds for justifying the gerle use.

The Cantal PDO zone includes all communes in the Cantal department, plus some twenty in the Puy-de-Dôme department and some in the departments of the Aveyron, Corrèze, and the Haute-Loire. The Salers PDO zone covers $4250 \mathrm{~km}^{2}$, centred on the Cantal volcanic massif. Natural conditions here are satisfactorily homogenous. The area is wholly enclosed within the $7200 \mathrm{~km}^{2}$ of the Cantal PDO zone.

\section{The Great Gerle controversy}

The gerle is key to the development of the specific character of Salers cheese, thanks to the role of the microbial flora present in the wood. It is used in the first stage of production when the curds are formed. The gerle is integral to product specifications and an essential feature of the Salers PDO production methods. The decree of 14 March 2000 enforced compulsory use of the gerle, with a dispensation (until 2003) for producers using stainlesssteel tanks.

The French INAO is the administrative body responsible for final validation as a compulsory set of obligations. For the sake of transparency and formal democracy, the procedure is available to all parties concerned. The final decision is made by the French ministry of agriculture and published as an official specification, which is then proposed for the European register. Every producer complying 


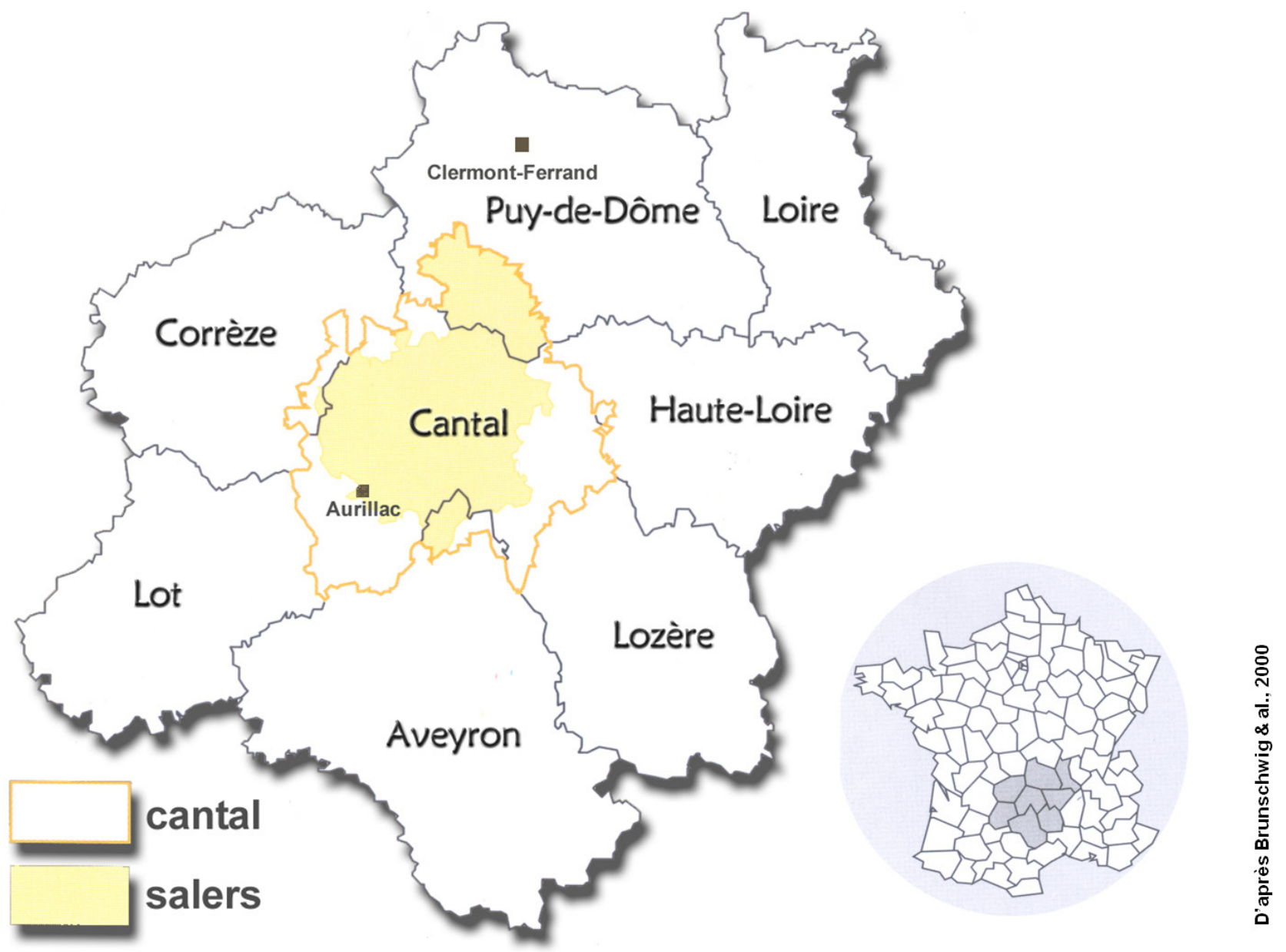

FIGURE 1. Cantal and Salers PDO areas (source: Brunschwig et al., 2000).

with the requirements (localization, production rules, and effective assessment) is then entitled to use the protected designation.

As the 2004 deadline for the switch to the gerle was approaching, a major conflict erupted over its use: faithfulness to this tradition was costing Salers producers dearly indeed. Suddenly their future hung in the balance after a group of Salers producers challenged the use of the gerle in the context of sanitary regulations. Despite the lack of evidence of food poisoning from PDO Salers cheese, they alerted the French Health Ministry to the potential risks from this form of production. This alert led the Cantal DSV (public administration in charge of food safety and sanitary regulation) to assess the microbial safety of the cheese in terms of EC regulation (Directive 92) on the grounds that more than half the cheeses produced did not comply with the bacterial standard (presence of Listeria monocytogenes and high level of Staphylococcus aureus).

After an audit of every PDO Salers cheese producer by the CIF, this professional body defined a safety plan, based on a self-assessment of the microbial level in line with the criteria of EC regulation, backed by individual help to the producer. With this plan in place, a committee was formed under the control of CIF, reporting to DGAL (French public food authority), INAO, and DSV. It was then that DSV required that the producers control cheese safety in a stainless tank before the use of the wooden gerle. This decision disregards the gerle's function and its capacity to provide its own fermenting. It denies the specificity of the producers' practices and the competencies on which they rest. The local representative for the INAO agreed to derogate temporarily for the use of the gerle to resolve this situation as some producers were prohibited from manufacturing simultaneously in a stainless tank and a wooden gerle.

The DGAL, DGS (French health public authority), and DGCCRF (French competition, consumer, and antifraud public authorities) sought scientific advice from AFSSA (the French food safety agency) about the sanitary situation and risks. AFSSA concluded that the S. aureus risk was not linked to the use of the gerle, but to the sanitary conditions of the herds. Despite the AFSSA's positive conclusions, and a real improvement in the safety quality of the cheese, the same group made fresh representations in 2005, pointing out the sanitary risks and the 
problems of compliance with EC regulations. Their aim was to have the INAO revise its decree and authorize the use of either the wooden gerle or stainless-steel vats. At the same time, a group of producers argued that the gerle was necessary for the cheese's sensorial qualities, cultural heritage, local know-how, and product image. At the end of 2005, a "commission of inquiry", composed of professionals and scientists nominated by INAO after consultation with all players in the supply chain rendered a favourable opinion for the gerle. The controversy then died down, thanks to local producers who crystallized the issues at stake, with input from local research and training centres studying the role of wood (Callon et al., 2004; Didienne et al., 2012). After that time, every Salers producer who submits a proficiency statement is required to pass a series of product safety tests prior to authorization.

\section{AN AMBIGUOUS SET OF RULES}

The gerle is the centrepiece of pressure and controversy, but behind it lies a more general difficulty: building a sense of collectivity around co-existing differences that are hard to reconcile such as the Salers and Holstein breeds of cattle, gerle capacity ranging from 400 to 1000 litres, and cheeses made from herds grazed in lush summer pastures or on the plain.

In practice, product specifications are open to interpretation. The result is a wide variety of farming methods and the coexistence of different, sometimes conflicting models within a growing business sector subject to strong hygienic pressures. These two factors have a disruptive influence on the supply chain as a whole.

\section{Technical choices of a very different kind}

A brief summary of recent economic history can explain the way things stand today, as surprising as they may seem. That coexistence of unrelated production systems is the legacy of cultural mores and standards that have been handed down through the generations. A handful of purists and enthusiasts remain devoted to traditional production and continue to move their herds to summer pastures where they make cheese in a "buron" (shepherd's hut), using milk produced exclusively by nursing Salers cattle, when open-air milking is particularly difficult due to the presence of the calf. The number of such producers grows smaller every year but they enjoy a firmly established status. Others also make cheese from herds grazed in mountain pastures, but from the milk of Montbéliarde cattle. The vast majority, meanwhile, make cheese on the farm from the milk of Holstein, Montbéliarde, Abondance or, much more rarely, Salers cattle. The size of a herd ranges from $40-100$ or even 150 head on large farms.

Some producers have turned to tourism and sell part of their output direct to the consumer. Others sell milk to cooperatives and commercial dairies. The production of fresh free-range Cantal cheese (in its unrefined state) has all but disappeared because of the very low price given by the ripeners for the fresh cheese. Salers cheese thus has effectively taken the place of authentic, free-range Cantal, which is now rarely available at the local level.

This heterogeneity is compounded by a relatively large production area that extends across three distinct regions: the Monts du Cantal, cradle of the appellation, the Aurillac Basin (plain), and the Cézallier plateau which includes the Saint-Flour and Planèze plateaus, where the cultural pattern is weaker. The latter are characterized by more clustered farm settlements (Durand, 1946; Fel, 1962) that may be some distance from the grazing meadows, forcing herders to use a mobile milking unit and transport the milk back to the farm to make it into cheese.

The organization of the work is also diverse. Some farmers employ a professional cheese-maker, so that herd management and milk processing are the responsibility of two people of different status. Then again, many farms are run entirely by the husband and wife who divide the tasks between them depending on their skills and inclinations. Whatever the case, the workload is considerable, at a time when the cost and shortage of labour make it increasingly difficult to maintain a traditional, labour-intensive farming system (Bordessoule, 2006).

What does it mean to own a herd of Salers, Holstein, or Montbéliarde cattle? What criteria determine that choice and what are its implications for overall organization?

For centuries, the Salers breed, lynchpin of the traditional Cantal farming system, has imprinted its rhythm on local society. The maternal character of the cow and her devotion to her calf, often mentioned by herders, has a very real effect on milking. Today, as ever, she will only produce milk if her calf is close by. The intimate relationship between the herder and the cow is evident from a variety of factors such as the naming of the calf and the way the herder calls it to its mother's side then ties it to her leg to prevent suckling during milking.

Average milk output from a herd of Salers cattle is approximately 3500 litres per year, and the animals are almost exclusively fed on grass. The milk's composition is particularly well suited to cheese making. By suckling at the end of milking, the calf takes the milk that is richest in fat, modifying the composition of the milk that is used to make cheese. In triggering letdown, the calf also cleans the teats with its tongue. Small-scale ripeners who work alongside Salers herders all agree that only Salers cheese made from Salers milk can withstand the prolonged ripening required for the full development of the aromas. Some ripeners say that the difference is evident within five to six months of ripening and can become quite remarkable after 24 months. This type of husbandry goes hand in hand with the use of gerles with a capacity never greater than 3001 ., and methods of production that require no fermenting agents. Based on these production principles, the cheese has the characteristic taste and appearance, especially in terms of the rind. In the end, the choice of breed cannot be considered in isolation. It forms part of an integrated, harmonious approach to production. This is particularly true of the Salers breed that serves as 
a model for a production system based on seasonal calving and pasturing systems. However, the number of herders is decreasing every year:

\begin{abstract}
...in 2007, less than ten herders were known to make cheese from high-pasture Salers milk. For the rest, methods are so mixed that detecting principal trends would require detailed analysis. Methods of animal husbandry are distinguished not so much by the breed of cattle as by the intensity of production practices that tend to depend on the location of the farm (Brunschwig, 2000).
\end{abstract}

The "Holstein system" described by one breeder defining his particular livestock practices -80 cows, pasture rotation with concentrated feed supplements, free stalls, and a milking room - might apply equally to numbers of Montbéliarde breeders. Some Montbéliarde breeders also tend to have the largest gerles (more than 10001 . capacity) and the largest milking units and are nearly twice as numerous as all the other Salers producers combined: there are 44 Montbéliarde herders compared with 14 Holstein, barely 10 Salers and an indeterminate number of herders with crossbreed cattle.

Therefore, the choice of breed does not necessarily imply very different patterns of livestock breeding. Different milks do in fact have different effects on cheese production. According to some ripeners, Salers cheese made from milk with high fat content seems to have a shorter aging period. Some producers get around the problem by partially skimming the milk. ${ }^{3}$ Others curdle the milk differently: rather than leaving it to curdle slowly as required by the traditional method (so as to retain the maximum amount of solids), they swirl it around quickly in order to separate and "lose" some fat content. These differences were readily visible in our video recordings. Producers with Salers cows kept the maximum of fat while producers with Holstein cows removed a great quantity of fat. It follows that an old code of practice written only for the Salers breed is no longer relevant to all farmers.

Naturally, not all Montbéliarde breeding is intensive. Most of the herds range from 40 to 60 head and some breeders continue to use the methods they applied when they were using Salers breed.

Our Montbéliarde cattle know just where to stand, always in the same place, just like we teach them, train them like we trained our Salers cattle. Hard work minds you...Montbéliarde cattle are the closest to Salers (interview to a breeder).

In winter, a few continue to make small quantities of free-range Cantal, curdling the milk in stainless-steel tanks (not in gerles). But most simply sell their milk to commercial Cantal cheese plants. The cattle diet is modified accordingly, with particular emphasis on output since until very recently Cantal production specifications contained few restrictions on cattle feeding. Therefore the most productive systems are also the most profitable, supported by a technical monitoring programme that aims to develop the most hygienic practices.
The Salers cheese specifications that were originally drawn up to distinguish it from Cantal leave too much room for varied and sometimes contradictory technical choices. A diversity of products is derived from production systems that revolve around various breeds, with safeguards to make production consistent. Differences are amplified by the varying length of the supply chain, ranging from direct farm sales with relatively low prices for local customers to ripeners selling to specialized retailers in distant towns at much higher prices.

\section{Diversity and Gerle use}

Public uproar threatened to put an end to Salers production altogether. Producers split into two fiercely opposing camps, represented by two separate associations, for and against the gerle. It is difficult to explain the violence of this controversy. It has something to do with the cultural pride of using this tool. In fact, it is more difficult to curdle raw milk in a wooden container that in a stainless steel one. Producers must learn to use it; it is part of collective local know-how. A number of new producers have learned to make Salers in a stainless steel vat and they refuse to take the sanitary risk of using a local tool that doesn't make any sense to them.

What I do not admit is that it is the gerle, they are so incoherent things, one is under the constraint of hygiene and one makes us take risks! (interview to a producer using a 12001 . capacity gerle).

At the other end of the chain are the producers for whom the gerle represents all. "If the gerle had been lost we would have stopped" (interview to a producer using a 450 1. capacity gerle). Producers in the heart of the production zone are more attached to the gerle than those in the border areas.

The controversy over gerle use dramatically illuminated all the difficulties of establishing hygiene standards compatible with tradition. It also revealed the local tensions when tradition is not lived in the same way, perhaps far from it, by the various actors of the sector. To keep gerle use or to remove it rests on arguments belonging to various registers. Those declared against the gerle, the minority, do not account for the particularity of this container and treat it as a stainless tank. For the others, the gerle "works" if its use is correctly "carried out".

But the health issue has led to greater confusion and disrupted production methods, raising doubts and forcing an unnecessarily detailed exploration of the management of microbial ecosystems. Gerle maintenance - rinsing with whey, scrubbing after use, priming at the start of the season- is an example. How should the condition of the gerle and the qualities of the raw milk be handled? Is the aim to implant the beneficial microbial biofilm on the surface of the gerle? On the one hand, it is necessary to maintain a balanced microbial population (lactic acid bacteria and non-lactic acid bacteria separated into Gram 


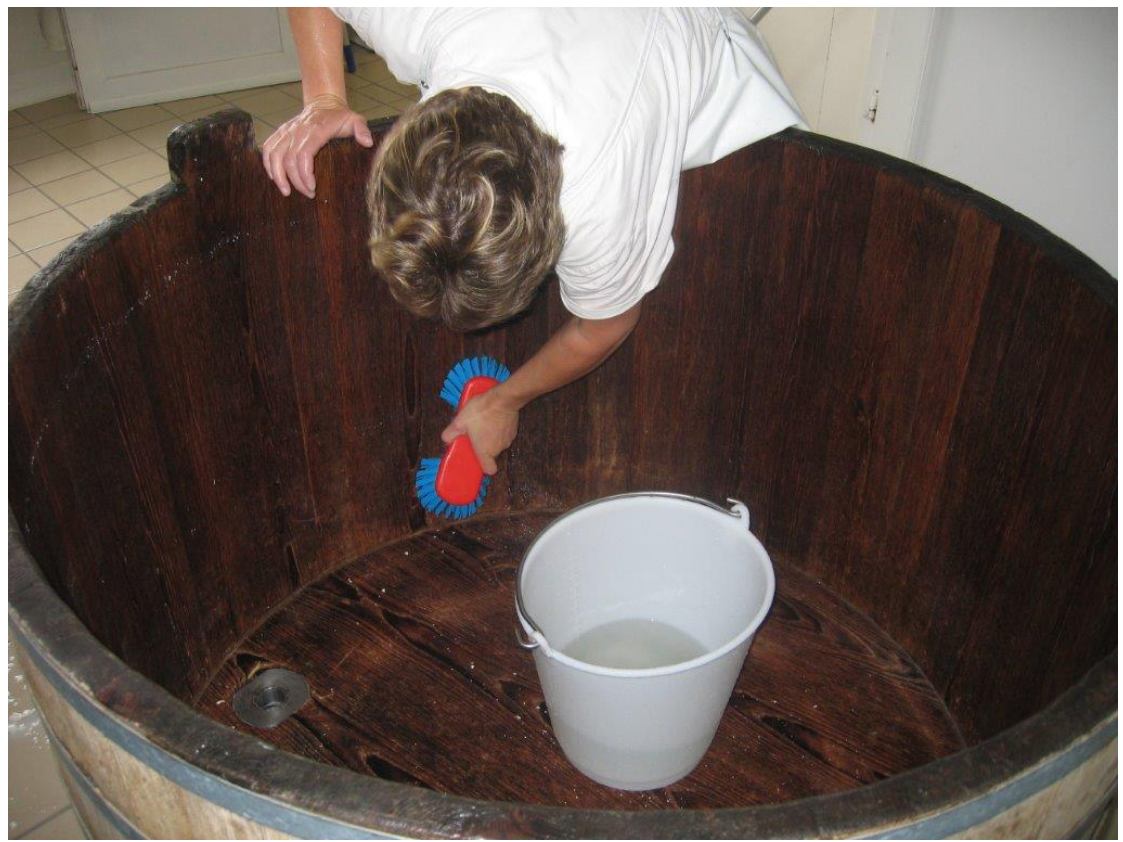

Рното 6. Cleaning the « gerles » in order to respect the microbes for the next cheese fabrication (Caldeyrou Arpajon).

positive and Gram negative yeasts and moulds) that work together for the development of the product's flavour. On the other hand, it is necessary to eliminate pathogenic bacteria to comply with EC regulation (Didienne et al., 2012).

The practices entailed here are difficult for producers to justify since they find themselves in unfamiliar territory, called into question on the status of their habitual expertise. As tensions mount, some producers try to avoid the risk of sanctions by adapting their working methods. New security rules appear that make no sense to the producers themselves, particularly those requiring excessive cleaning of the gerle (with boiling water and detergent) and the often needless addition of fermenting agents. Such use is often suggested and sometimes enforced by ripeners, who acquire undue influence on the finished product. However, there is a broad range of answers which reflects more or less self-confidence, capacity to impose knowledge, and perseverance to explore this difficult field of microbes. The size of the gerle, which is not regulated, is another very disturbing element in the coherence of practices.

Such diversity becomes a real problem for the supply chain itself. There are too many diverging interests, and the players involved have too few reasons to find common ground. The Salers cheese sector has the character of a highly heterogeneous set of individuals, not a real collective. Differences such as cattle breed, pasture type, and herd size are in effect a collective weakness. The great "gerle" controversy, that jeopardized the Salers sector, also demonstrated the difficulties of grouping such dissimilar producers under a single PDO.

\section{A COLLECTIVE FACED WITH DIFFICULTIES}

This is a critical moment in the reform of certification and inspection authorities, so it seems timely to ask questions about the role of local knowledge in relation to collective action. The Salers cheese sector was traditionally managed by the same "Syndicat de Defense" as the Cantal sector. Now that it has its own governing body, it is learning how to function as a collective. Given the context, it is difficult to see how collective action might be organized for the protection and development of Salers cheese production.

\section{How to deal with Heritage?}

Many of the current difficulties arise from the fact that Salers cheese was abandoned by the previous generation and then recently revived. The continuity maintained by some producers exists alongside innovations introduced by others, reinforcing the characteristic heterogeneity of the sector - a sector nonetheless founded on the stricter observance of authenticity. The initial break came in a period marked by major agricultural upheaval: changes in herd composition and new feeding methods that included the introduction of silage. The return to traditional production methods occurred under very different conditions, which may be the problem: "there is just 'too much room for free play'. The limits of that free play might have been better defined" (Ostrom, 1990), if product specifications had focused more thoroughly on the pressure points, and had done so sooner. 
For instance, Salers specifications did not originally include the compulsory use of the gerle. As a result, several newcomers learned to make the cheese in stainless steel tanks, particularly in regions where the model was less culturally rooted, such as the Aurillac Basin and the Cézallier plateau. Use of the gerle was made compulsory by the very last decree, representing a major victory for those in favour of more traditional methods. For the time being however, there are no regulations covering either the capacity of the gerle or the choice of breed, which is left to the discretion of individual herders. In practical terms, it is plainly as important to regulate these two factors as it is to regulate seasonality or free-range production. Otherwise such gaps in regulation encourage a drift that creates problems for the general consistency of the sector and its capacity to form a collective (Casabianca et al., 1993).

The discrepancy in this area underscores the affinity that exists between the most intensive producers and industrial cheese makers. They share the same mentality and account for a large part of the Salers sector in terms of quantity. The cheese they make is very similar to Cantal and based on much the same principles. They receive advice from the big Cantal dairy firms. The fermenting agents are the same and the oversized gerles serve little or no practical purpose, their use being in any case hotly contested by industrial cheese producers. Advocates of the traditional wooden gerle were outraged when someone suggested "wrapping" a stainless steel tank in wood. Nevertheless, Salers cheese is good business and industrialists would love to steer production in a more homogeneous direction. Their influence, however, is disruptive to the identity of Salers and fosters rifts within the sector.

The specifications do retain certain strong points and economic conditions remain favourable. The gerle itself has particular significance in terms of the producers' general perception of things, the production problems associated with the use of a wooden container, and of the limit to what may be shared by "authentic", "opportunist", and "new" producers alike (although they are all, in a sense, "newcomers"). This sharing - recent for some producers - is still more theoretical than actual, which does a lot to explain the weak response to administrative injunctions at the time of the disagreement over hygiene.

The Salers breed plays a key part in positioning the whole sector. Referring as well to the name of their cheese, the fact that this cattle breed became marginal makes producers feel nostalgic for the animal and sad to give it up. But there is also a clear, often first-hand awareness of the difficulties entailed. An ever-smaller handful of producers remain passionate about the lifestyles associated with the breed, however harsh.

The heritage of the Salers breed, as illustrated in many fine books, is proving particularly difficult to manage. The omnipresent, powerful image of the Salers cow - from its touchingly maternal behaviour to the cheesemaking methods and places that it stands for - tends to backfire in a disruptive, uncontrollable fashion:
There's a huge festival in Allanches in celebration of the herd's movement to summer pasture, but it's misleading because Salers cattle now play only a marginal role in the production of Salers cheese (interview to a ripener).

One can well imagine how embarrassing this is for the producers.

A similar difficulty is raised by the image of the "buron", the little cheese house that was traditionally used by people in the mountain season. When the Salers PDO was created, these burons were numerous and had their place. Nowadays they are disappearing. But should the PDO allow this foundation myth to perish with the last buron? They may no longer be a model for the young producers (the way of life is really too removed from present lifestyles); still, this heritage question is a heavy responsibility.

\section{Diversity of local knowledge: strength or weakness?}

Until now Cantal and Salers cheese production shared a common syndicate, with a marked imbalance in financial contributions to their joint trade association, the CIF. What can we expect to happen following the INAO reform currently underway? The rifts resulting from the handling of the crisis ran deep and threaten to re-open. Added to this is the sheer workload entailed in twice-daily cheese production, each fresh 'tome' taking at least three hours to process. Producers are also very isolated from each other, scattered across the zone. All of this helps to explain why there is so little collective feeling, in terms of the points of view expressed and the behaviour patterns observed.

As mentioned, the new legislative reform of the ODGs has led to a big change in the existing structure by creating a Salers section within the CIF. This first step towards self-organization represents a golden opportunity to build much needed cohesion within the collective. Producers or their representatives can come to terms with principles of collective responsibility that have so far largely eluded them.

In the end, the weight of tradition symbolized by the Salers breed - summer milking and cheese-making in a "buron"- puts too great a mental and psychological load on many of the current Salers producers. Will they have what it takes to move the rules forward, towards production systems that are more practical and viable in economic terms, and dispel tensions arising from models that are no longer socially acceptable today? Authorities such as the newly formed Salers section plainly provide the conditions for producers to move in this direction, and reduce the seemingly excessive diversity of current practices.

The Cantal PDO illustrates one possible approach: choose the more efficient or more frequent technique, and add that to the code of practice as a rule for all producers. In reality, this normative approach seems irrelevant to the current circumstances of the Salers PDO. 
We reported our results directly to the new Salers section, as material for internal debate. Mainly, we suggested that not all differences between producers deserved the same approach. Some differences add strengths worth preserving, while others contribute to collective weakness. The real discussion must focus on the distinction between these two categories, and efforts be focused accordingly. Debate has to focus on the product itself, on the way it is perceived, and on local skills and knowledge. It has to bring together farm processors and ripeners. After spending so much time and energy on sanitary issues, it is time to pay attention to the quality and typicality of the product. From these obligations of results, it becomes possible to approach diversity of technical choices and productive practices in a new way. The main message delivered to the Salers section was therefore directed towards the major difficulty it encounters: to select between (1) what must absolutely be maintained in the variety of the situations of production, and (2) what should be regarded as a dangerous heterogeneity for collective action and the shared identity. The results can clarify this necessary selection and mitigate its potential conflicting effects.

This way, the particular orientation of each producer should be to enable the milk, the young cheese, and the ripened cheese to be part of the PDO. Maybe the Salers section should consider different categories within the PDO (the Cantal PDO includes three types). That way, the legitimacy of each current alternative might be addressed from a collective perspective, and not merely as individual choices. Such an approach should give the Salers section the spirit of trust it needs to face up to the changes that have to be made, the rules that have to be tightened, and the decisions that have to be reached and enforced. These rules relate to a variety of local resources that have an impact on the special nature of Salers cheese. Obviously, some choices are more reversible than others, particularly the choice of the gerle wood, the capacity of the gerle - crucial for the effectiveness of the microbial ecosystem - and the use of fermenting agents. Pragmatically, it could be proposed that the extension services acting locally give some help to the producers during their learning period, thus making a shortterm change feasible.

Other choices impact the production system itself and seem to be harder to reverse. In particular, the size of herd and the choice of breed appear to be out of the present debate within the Salers section. If such changes are considered necessary, some transition period must be imagined in order to allow producers to comply with the new rules in the long term.

Such learning processes should dramatically reinforce the sustainability of the Salers PDO sector. Salers producers must now come to appreciate the full significance of this gerle issue, and so rebuild their confidence and project themselves as a group (Olson, 1987). Does the issue create a fresh base from which the group will emerge with a renewed understanding of tradition and their sociocultural heritage? In the end, what seems to bind these different players together is their passion, sometimes a passion for the Salers breed, but mainly a shared passion for making cheese. Time and again we were told that "you have to love this job". In terms of local dynamics, we think it essential to define local knowledge as the resource that reinforces the relationship among producers and promises to cement the entire sector.

\section{CONCLUSIONS}

\section{A Salers Actor Network}

The ANT conceptual framework acknowledges the fact that agrarian know-how is dynamic and interactive, and that it forms the relationships between farmers and their cattle, between ripeners and the gerle, even between hygenists, producers and the microbes themselves. ANT takes power to be the effect or result - not the cause - of dynamics and interactions among actants. For instance, as we have shown for the gerle, its sheen of microbial action can assist small producers, or, hindered by harsh cleaning agents, shift power to ripeners and larger manufacturers. This managed diversity - the discontinuous, interlinked, and often contradictory local knowledge - is the source of the renowned high quality of the Salers cheese product and a source of power for smaller artisanal producers, yet it also has hindered development of the label as a regulatory instrument, and for somewhat different reasons, the cooperative relations among sector members. As ANT suggests, this knowledge-diversity nexus can become the basis for an empowered agrarian sector (Scott, 1998), and raises important questions with respect to how the loss of even marginal practices might affect knowledge, power, and quality, if differences can be sufficiently overcome to permit the collaborative efforts necessary to solidify the specifications and manage the PDO.

Our analysis was conducted by an interdisciplinary research group including specific expertise in herd management and the effect of wood on production, fields directly related to Salers production efficiency. The decision to focus on local skills proved fruitful, providing opportunities to assess the consistency of the different systems used by the producers interviewed. A real actor network is emerging, including cattle, microbes, wooden tools, and cheeses, not only people. The competencies that each one represents serve as links between the various actants.

\section{The Salers section: A new arena for the PDO governance}

Local practices are considered here for what they are and what they represent to those who use them. All of these practices relate to characteristic product features created by the producers involved. This perspective is essential to understanding the resources that must be reinforced for the sake of the production system in question, and the rules that must be tightened. 
The newly created section could provide a forum for discussion, debate, and development of collective rules. The range of knowledge and know-how now gathered could serve as material for these discussions, and become the essential link between producers. In particular, we hope that the distinction between diversity as strength and heterogeneity as weakness would take the personal element out of the debate. Effective distribution of knowledge can enhance internal democracy (Latour, 2004) and encourage the collaborative production of new features that better favour convergence between producers.

Given this context, the now-compulsory status of the gerle may be seen as a decisive victory for the future of the cheese and those who make it:

A well-earned reward for the effort expended on obtaining approvals and surviving despite the disturbing proximity of the mighty Cantal industry. The introduction of new hygiene rules led to some serious soul-searching at every level, forcing administrators and veterinary services alike to justify the criteria on which they granted or refused approvals. Seen in this light, the gerle outcome is an example for all special production systems that, like the Salers sector, find themselves in conflict with hygiene restrictions that challenge traditional practices (Bérard and Montel, 2012).

By chance, the Salers sector was the beneficiary of strong support from INAO, CIF, and microbiologists with expertise on fermented foods. But, as it was noticed during the crisis, when a great heterogeneity (affecting methods and technical choices not easily reversible) is associated with a strict hygiene restriction, the whole production system is endangered and can be destroyed. At the present stage, even in the Salers situation, nothing is really insured for the long term if the heterogeneity is not reduced and the convergence among producers is not increased. One condition of achieving this objective is that tradition must make sense for most of the producers sharing the same idea of what to do with common heritage. The future of such typical cheese sectors seems to be at the price of facing these paradoxes of local knowledge. The task at hand is to work together to distinguish divisive heterogeneity from sustainable diversity, and work toward cultivating the latter.

\section{ACKNOWLEDGMENTS}

This work was carried out with the financial support of the "ANR" (The French National Research Agency) as part of the «Agriculture et Développement Durable » program, in the project «ANR-05-PADD-012, Promotion du développement durable par les indications géographiques $»$. This project ended in 2009.

Our thanks to the CIF (Federation of PDO Cantal and PDO Salers producers) and the Aurillac INAO centre; thanks also for the contributions of all those local players (producers, ripeners, technicians, and "gerle makers") without whose help this work would not have been possible.

\section{NOTES}

1 Though ANT may help explaining the dynamic, inter-active, networking role of local agricultural knowledge in Salers PDO production, it does present an interesting ontological tension regarding essentialism. ANT is valued as 'one of the many anti-essentialist movements that seems to characterize the end of the century' (Latour, 1999: 20), yet GI and PDO are predicated on recognizing, fostering, valuing, and evaluating the essentiality of an agricultural product. Writing further on this paradox and its implications, particularly regarding recent critiques of patrimony, is needed.

2 The French INAO is the administrative body responsible for final validation as a compulsory set of obligations. For the sake of transparency and formal democracy, the procedure is available to all parties concerned. The final decision is made by the French ministry of agriculture and published as an official specification, which is then proposed for the European register. Every producer complying with the requirements (localization, production rules, and effective assessment) is then entitled to use the protected designation.

3 This practice was forbidden from 2010 onwards (Salers decree of 14 March 2000).

\section{REFERENCES}

Akrich, Marianne (1992) "The De-scription of Technical Objects". In Shaping Technology/Building Society. Studies in Sociotechnical Change, edited by Bijker, Wiebe E. and Law, John. MIT Press, Cambridge Mass: 205-224.

Bérard, Laurence and Marchenay, Philippe (2004) Les produits de terroir. Entre cultures et règlements. CNRS Editions, Paris.

Bérard, Laurence and Marchenay, Philippe (2008) "Les productions traditionnelles aux prises avec les normes sanitaires". Economies et sociétés, série «Systèmes agro-alimentaires 》, 11-12 (30): 2273-2284

Bérard, Laurence and Montel, Marie-Christine (2012) "La gerle, le vivant invisible entre traditions et normes d'hygiène". In L'animal certifié conforme. Déchiffrer nos relations avec le vivant, edited by Lizet, B. and Millier, J. Dunod \& MNHN, Paris: 55-76.

Bordessoule, Eric (2006) "L'élevage dans la montagne volcanique auvergnate. Le modèle cantalien". In Acteurs et espaces de l'élevage (XVIIe-XXIe siècle), edited by Madeline, P. and Moriceau, J.-M. Association d'histoire des sociétés rurales, Caen, 9: 191-205.

Brunschwig, Gilles (2000) Terroirs d'élevage laitier du Massif central. Pôle fromager AOC Massif central. Enita, École nationale d'ingénieurs des travaux agricoles de Clermont-Ferrand, Lempdes.

Callon, Michel (1998) "Des différentes formes de démocratie technique". Responsabilité et Environnement, Janvier (9): 63-73. http://www.annales.org/re/1998/re01-98.html.

Callon, Michel (2004) "Actor Network Theory". In International Encyclopedia of the Social \& Behavioral Sciences, edited by Smelser, N. J. and Baltes, P. B. Elsevier, Amsterdam: 62-66.

Callon, Cécile; Millet, Liliane and Montel, Marie-Christine (2004) "Diversity of lactic acid bacteria isolated from AOC Salers cheese". Journal of Dairy Research, 71: 231-244.

Casabianca, François; Sainte-Marie (de) Christine; Santucci, PierreMathieu; Vallerand, François and Prost, Jean-Antoine (1993) "Maîtrise de la qualité et solidarité des acteurs". Qualité et systèmes agraires (INRA), 28: 313-358.

Czarniawski, Barbara and Hernes, Tor (2005) Actor-Network Theo$r y$ and Organizing. VA: Copenhagen Business School Press, Herndon.

Décret du 14 mars 2000 relatif à l'appellation d'origine contrôlée « Salers » (2000) Journal Officiel de la République Française, $\mathrm{n}^{\circ}$ $65,17^{\text {th }}$ March : 4155-4157.

Delfosse, Claire (1992) La France fromagère. Thèse de doctorat de Géographie. Université Paris I, Panthéon-Sorbonne, Paris, 3 chap. 6: 203-223. 
Devoyod, Jean-Jacques; Millet, Liliane and Rousseau, Micheline (1987) "Rôle de la vaisselle laitière dans les fabrications fromagères traditionnelles. Cas des fromages à pâte pressée demidure". In Histoire et géographie des fromages, edited by Brunet, Pierre. Centre de publications de l'Université de Caen, Caen: 53-65.

Didienne, Robert; Defargues, Catherine; Meylheuc, Thierry; Hulin, Sophie and Montel, Marie-Christine (2012) "Specificities of microbial biofilm on wooden vat (gerle) in PDO Salers cheese". International Journal of Food Microbiology, 156: 91-101.

Dove, Michael (1996) "Process versus product in Kantù Auguri: A traditional knowledge systems' solution to the problem of knowing". In Redefining nature: Ecology, culture, and domestication, edited by Ellen, R. and Fukui, K. Berg Publishers, Oxford: 557-596.

Dunn, Elizabeth C. (2003) "Trojan pig: paradoxes of food safety regulation". Environment and Planning A, 35 (8): 1493-1511. doi: $10.1068 / \mathrm{a} 35169$

Durand, Alfred (1946) La vie rurale dans les massifs volcaniques des Dores, du Cézallier, du Cantal et de l'Aubrac. Imprimerie moderne, Aurillac, France.

Foucault, Michel (1980) Power/Knowledge: Selected interviews and other writings 1972-1977. Pantheon Books, New York.

Fel, André (1962) Les hautes terres du Massif central. Tradition paysanne et économie agricole. Presses Universitaires de France, Paris: 223-240.

Fischer, Frank (2000) Citizens, Experts, and the Environment: the Politics of Local Knowledge. Duke University Press, Durham.

Knorr-Cetina, Karin (1999) Epistemic Cultures: How the Scientists Make Knowledge. Harvard University Press, Cambridge, MA.

Latour, Bruno (1988) The Pasteurization of France. Harvard University Press, Cambridge, Massachusetts and London, England.
Latour, Bruno (1999) “On recalling ANT”. In Actor Network Theory and After, edited by Law, John and Hassard, John. Blackwell/Sociological Review, Oxford, England and Malden, MA.

Latour, Bruno (2004) Politics of Nature: How to Bring the Sciences into Democracy, translated by Catherine Porter. Harvard University Press, Cambridge, MA.

Law, John (1999) "After ANT: complexity, naming and topology". In Actor Network Theory and After, edited by Law, John and Hassard, John. Blackwell/Sociological Review, Oxford, England and Malden, MA.

Mariani, Claire; Briandet, Romain; Chamba, Jean-François; Notz, Eric; Carnet-Pantiez, Anne; Eyoug, Rose Nadine and Oulahal, Nadia (2007) "Biofilm ecology of wooden shelves used in ripening the French raw milk smear cheese reblochon de Savoie". Journal of Dairy Science, 90 (4): 1653-1661. doi: 10.3168/ jds.2006-190.

Michel, Valérie; Verdier-Metz, Isabelle; Delbès, C.; Montel, MarieChistine and Chamba, Jean-François (2008) "Diversité microbienne des laits crus : quels enjeux, quels risques, quels moyens de gestion?". In Colloque international sur les indications et appellations d'origine géographiques (AOP-IGP) : Enjeux et acquis scientifiques, coordinated by INRA et INAO. Paris: 6371.

Olson, Mancur (1987) Logiques de l'action collective. PUF, Paris.

Ostrom, Elinor (1990) Governing the Commons: The Evolution of Institutions for Collective Action. Cambridge University Press, Cambridge.

Ricard, Daniel (1994) Les montagnes fromagères en France. Clermont-Ferrand, Ceramac, Université Blaise Pascal: 349-444.

Scott, James C. (1998) "Seeing like a state: How certain schemes to improve the human condition have failed". In The Institution for Social and Policy Studies. Yale University Press, New Haven, CT. 